\title{
The Evolution of the Party System and Cleavages in Post- Communist Hungary
}

\author{
Crina Sămărghitan,Victor Cioară, Sergiu Gherghina, Adrian Muică \\ Crina Samarghitan, Victor Cioara, Sergiu Gherghina and Adrian Muica are senior students at the \\ Babes Bolyai University with a particular interest in party systems in post-communist countries.
}

ABSTRACT: The post-Communist countries suffered many transformations in a short period of time; their political, economic and social system is in a continuous change. All the countries from Central and Eastern Europe try to cope with the Western political systems, try to avoid the third wave of authoritarianism, wave that usually comes after a democratization one. One country's political system is impressing and interesting in many ways. We decided to approach and to analyze only a part of the political system in a country that relatively succeeded on its way towards democracy - Hungary. The evolution of Hungarian cleavages allows us to identify the emergence of parties and from that point on to deeply analyze the party system from 1990 until now. One main advantage of our study is that we make a dynamic evaluation of the party system, using some variables that were applied in the case of other party systems. The variables and indicators were used by well-known scholars to observe some variations in the Western party systems and to realize some categories. The conclusions obtained have a degree of specificity; they cannot be entirely applied to the countries in the region. The research can be improved by analyzing the electoral system and by searching new indicators for the already used variables.

The Due to the big transformation suffered by Hungary in political level in less than 15 years, the evolution of the party system is very interesting from several points of view. The paper is, basically, a Western approach applied in the case of Hungary. The goal of the paper is to observe the trends and the patterns in the evolution of the party system since 1989 the ways in which this evolution fits into or departs from the model presented by political scientists for Western political systems.

\section{Conceptual Clarifications}

As a first step in our analysis, we will specify the conceptual framework that we will use in the paper. It is important to define the notion of "party" because it represents the main unity of the party system. In this regard, we can use the minimal definition elaborated by Sartori $^{85}$, or we can use a broader definition ${ }^{86}$. We will consider another definition, a version of the minimal one, that is Giovanni Sartori's definition ammended by Peter Mair "We qualify as political parties all the organisations that (having as goal the right to participate in the exercise of political power) participate (by presenting candidate) in elections (free or not) organised inside the political regime ${ }^{187}$. The party system, like any other system, has several

\footnotetext{
85 György Markus, Party Politics, Party System and the Dynamics of Political Cleavages in Hungary, Budapest, June 1998, pp. 12-13

${ }^{86}$ ibidem, pp. 13

${ }^{87}$ Gyorgy Markus, op.cit, pp. 33
} 
parts, susbsystems, which interact making possible what we call "system consistency". .Lane and Ersson think that " a party system is consitued by a set of political parties that operates inside a nation following a pattern characterized by several systemic properties $^{\text {" } 88}$ while Duverger considers that " $a$ party system is defined by a particular relation between features like: numbers, measures, aliances, geographical locations, political distribution etc" $" 89$. If Duverger is focussing on the system characteristics, Sartori choses to focus on a system of interactions resulted of interparty competition. $^{90}$.

As it can be seen, the researchers have been preoccupied with identifying the party system's features / properties on whose basis they built their own classification or typologies. Lane and Ersson found two that are predominant - the electoral participation and the number of parties, this is the well-known Duverger's classification based on numerical criterion. According to Duverger, the party system is classified as one-party system, two party system, Anglo-Saxon type, and multiparty system ${ }^{11}$. Jean Blondel considers that there are four types of party systems: two-party system, twoand-a-half party system, multi-party system with a dominant party and multi-party system without a dominant party $^{92}$. R.A. Dahl has a typology based on four dimensions ${ }^{93}$, a typology that makes a distinction between

${ }^{88}$ Gyorgy Markus, op.cit. pp. 7

89 Herbert Kitschelt, Formarea sistemului de partide în centrul şi estul Europei, PolSci, pp. 21

${ }^{90}$ Gyorgy Markus, op.cit, pp. 8

${ }^{91}$ ibidem, pp. 8

92 ibidem, pp. 8

${ }^{93}$ ibidem, pp. 8 the two-party systems and multiparty systems divided according to the internal unity (big - small) of the parties $^{94}$. Lipset and Rokkan have their own typology that stresses the impact of cleavage lines in configuring parties and party systems ${ }^{95}$. The final typology, the Sartorian one, is possibly the most explicative because it introduces a new dimension (besides the numerical one), the ideological distance. We will use the latter as our choice regarding the analysis of the party system in Hungary.

In stasiology, the political parties' science, the evolution of the Western European party systems can be characterized, as many researchers have concluded, by a high degree of continuity. Representative for this direction is the hypothesis of frozen party system elaborated by Seymour Lipset and Stein Rokkan: "the party systems from the 60's reflect, with few but significant exceptions, the cleavage structure from the $20^{\prime} s^{96}$. This hypothesis does not seem to be very actual because of the new research direction, theme of party failure $^{97}$. If in Western Europe the issue is still questionable, in Central and Eastern Europe, the parties did not evolve in the same direction. The main reason for this, which we cannot discuss in the same terms, is the fact that the development of Central and Eastern European pluripartism and democracy were interrupted by the events that occurred after World War II. Taking this into consideration, the development of the party systems in this part of Europe present a different configuration compared with the

\footnotetext{
${ }^{94}$ idem, pp. 10

95 ibidem, pp. 10

${ }^{96}$ Gyorgy Markus, op.cit, pp.10-11

${ }^{97}$ Gyorgy Markus, op.cit, pp. 36
} 
Western European ones. Thus, while the pluripartism characterized the Occidental democracies, the one-party system was the dominant structure of Eastern popular democracies ${ }^{98}$.

\section{Cleavage Evolution}

The cleavage between modernization and the nationalist traditionalism knew a real development; it had its roots in the substance of modernization as a historical, social and cultural process. The problem was how to combine better the universal and the particular, the past with a vision of the future, the traditional patterns with the modern ones. The cleavage has not been for ever something very clear and very intense. In some moments of history, like the "reform age" before 1848 and during the national revolution from $1848 / 49$, the modernist and patriotically forces were able to become allies. The traditionalists supported a type of modernization based on value keeping and on national cultural identities, like in Japan. They stress on the idea of Hungary as a nation and they favor the strong authority, the powerful church and the strong community, ignoring the society. The traditionalism was not limited to a single class, to the church or to a certain period. On the other side, the Occidentalists were in favor of modernizing and individualism, of multicultural diversity, secular state, human rights. They looked outside their country using arguments from sociology and searching the development of civil society. They accepted the borders of the state and regarded the Hungarian minorities abroad as a human rights question ${ }^{99}$.

${ }^{98}$ Gyorgy Markus, op.cit, pp. 10

${ }^{99}$ Szasz Alpar Zoltan - Partide şi sisteme de partide, UBB Cluj-Napoca, Centrul de Formare Continuă şi Învățământ la Distanță, 2003, pp. 62
If in Western Europe, the parties were stabilized on the cleavage basis, in Hungary, the parties were an initiative of elite's network. From this type of creating the parties we can see two characteristics - the competition between parties has a tribal character, a powerful emotional character; the parties have unclear profiles and they do not offer clear policies alternatives, but they present themselves to the electorate by different images in the media. Though the Hungarian party level was characterized by the domination of political culture, the central cleavage of traditionalism vs. Occidentalism was a sum of territorial and cultural cleavages.

The shock therapy as a cleavage creating politics ${ }^{100}$

The socialist-liberal government reaction from 1994 to the previous regime, overpoliticised and its attempt to revitalize a middle class consisted in adopting a strategy of depolitisation in the media and a technocrat approach in solving the public policy problems. The management of technocratic crisis became very important in March 1995 when, after 9 months of conflict due to the coalition and inside $\mathrm{MSzP}$ it was proposed a radical policies package, the Bokros Plan, which pursued a general monetary restriction and the financial equilibrium.

The cleavages changes, as they were defined by the parties' elites, had an amazing effect on the cleavages among parties. As a consequence of the Bokros Plan, the opposition adopted a social-democrat line, even

\footnotetext{
${ }^{100}$ Janusz Bugajski, Political Eastern Europe.A Guide to Politics in Post-Communist Era, Armonk, New York-London, The Center for Strategic and International Studies, M.E.Sharpe, pp. 349
} 
Keynesian, which was characteristic to a welfare state. Ferenc Kulin, a moderate conservative, a well-known MDF politician justified this change admitting that the central ideas of the traditional-patriotic parties and the political attitudes of the electorate cannot be changed. The only party that did not have problems in adapting the new realities was SzDSz. The Bokros package affected SzDSzvoters, but it was compatible with the liberal and original radicalism of the party regarding the regime changing ${ }^{101}$.

\section{Cleavage Families}

The cleavage structure in Hungary was identified by Gyorgy Markus in his paper Party Politics, Party System and the Dynamics of Political Cleavages in Hungary and it is deeply analyzed. Briefly, he identifies three cleavage families:

1. The territorial and cultural cleavages family:

The traditionalist forces stress on the historical continuity, the national Hungarian character, they favor the community against the society, and they are for a powerful church, for a powerful authority. Their value orientations are more particular than universal, stress on the rural area. The Occidentalists stress on the urban area, look the solutions outside the country, they favour the individualism, the multicultural diversity, the secularism and human rights.

2. The post-Communist cleavages family:

This set of cleavages has several dimensions:

- an ideological dimension of antiCommunism that can be based either on national, religious iden-

${ }^{101}$ Janusz Bugajski, op.cit, pp. 350 tities or on the human right universalism and rationality;

- a political dimension visible in the Socialist Party as the successor one;

- a power dimension of the competitor elites and a redefinition of the rules of the games inside and outside the politics;

- a structural dimension that reflects the dualism of the current society with a sector with roots in the Communism and with another one rooted in the capitalism;

- an emotional and biographical dimension with a population division in two halves- one that considers they lived better in the latter years of the "true socialism" and another one thinking different.

3. The socio-economic cleavages family

This set of cleavages became central starting with the economic transformation process and with an electorate that became overwhelmingly materialist. A pole of the cleavage family is the radical co modification in approaching the market economy, the privatization. Stressing on a primary distribution on the market regarding the welfare and reducing the inequalities on the market, the de-co modification pole regards a welfare state ${ }^{102}$. In Hungary and in similar democracies, the power processes and the welfare distribution were more or less completed. The parties analyzed in the "Ideological families" section correspond to the cleavage structure mentioned above; the criterion we used to select these parties was at least one

${ }^{102}$ ibidem, pp. 350 
Parliamentary performance after 1989. The scheme we have chosen to represent the cleavages in Hungary is different from the one Herbert Kitschelt uses in his study on Hungary ${ }^{103}$. The axes he uses represent the redistribution and spontaneous allocation on the market and cosmopolitanism vs. particularism. The two axes we preferred represent the cleavages after 1989 and the parties are situated in the scheme. The co modification and decommodification axis is the economic one, similar to that used by Kitschelt, but the generality degree of his axis is higher because he realized a comparative approach of many countries in the area and he used the same scheme for all of them. The axis with Occidentalists vs. traditionalists represents the powerful cultural cleavage that appeared after 1989 and which divides the parties in two camps. There are more cleavages that interfere with the ones identified, like the postCommunism vs. anti-postCommunism).

The Alliance of Free Democrats Szabad Demokraták Szövetsége $(S z D S z)$ - is characterized by radical Occidentalism, anti-nationalist, secular individualism and human rights, social libertarianism ${ }^{104}$.

The Hungarian Democrat Forum Magyar Demokrata Fórum (MDF) MDF was the hegemonic party of the traditionalist camp. It is characterized by a radical anti-Communist position; it preferred the co modification aspect. The Popular Christian-Democrat Party - Kereszténydemokrata Néppárt

103 idem, pp. 35

104 Allan Day et al., Political Partie of the World, $4^{\text {th }}$ edition, London, Cartermill Publishing, 1996, pp. 308
$(K D N P)$ is a historic traditional party rooted in a narrow Catholic culture; it combined an anti-Communist profile with welfare state positions.

The Hungarian Party of True and Justice - Magyar Igazság és Élet Pártja (MIéP) is a party of nationalsocialism; it combines the antiOccidentals, racist and antiCommunist positions with the vision of a powerful decommodification, the consolidation of the national state ${ }^{105}$.

The Hungarian Popular Democrat Party- Magyar Demokrata Néppárt $(M D N P)$ is based on a pragmatic antiradicalism, moderate traditionalism, moderate anti-post-Communism moderate commodification ${ }^{106}$

The Independent Smallholders' Party - Független Kisgazda Földmunkás és Polgári Párt $(F K g P)$ is an antiCommunist, anti-cosmopolitanism party but in the last period can be seen a tendency of moving towards center positions $^{107}$.

The Hungarian Socialist Party Magyar Szocialista Párt (MSzP) - is caught in the post-Communist cleavages in a double sense: its members, electorate, the traditions of decision-making, the political culture, the network are from Kadarian period, but the economic financial and professional elites they count on are from the capitalist sector. There is a certain contrast between the radical co modification politics from 1995 and the current preferences related with the welfare state ${ }^{108}$.

The Workers' Party - Munkáspárt (MP) adopted anti-co modification positions; its nationalism is similar to

\footnotetext{
${ }^{105}$ Janusz Bugajski, op.cit, pp. 352

${ }^{106}$ Janusz Bugajski, op.cit, pp. 354

${ }^{107}$ Allan Day, op.cit, pp. 308-309

${ }^{108}$ Janusz Bugajski, op.cit, pp. 355
} 
anti-clericalism, anti-Occidentalism (against NATO integration of Hungary) ${ }^{109}$

The Alliance of Young Democrats The Hunmgarian Civic Party * - Fiatal Demokraták Szövetsége - Magyar Polgári Párt (FIDESZ-MPP) can be considered a strategic party, it avoided the political cleavages. It occupies a center position that allows it to gather many votes. Its main characteristics are the opposition to Communism; they became, after a while, radical Occidentalists, secularists, antinationalists. Being a pragmatic party, it shaped its positions after each conflict or "divorce" between parties from coalition $^{110}$.

In the traditional parties camp two contradictory tendencies had occurred. The first one was a sum of cleavages, as a response to those sustained by the Occidentalist block:

decommodification related with a national-clerical and anti-Communist position. A direct consequence was the radicalization of party competition. A second tendency was the division between a militant and demagogical wing and a pragmatic one. Conflicts occurred inside The Forum and inside the Christian-democrats. In January 1996 half of the MDF Parliamentary group left the party and formed the moderate and pragmatic MDNP, The Hungarian Popular Democratic Party. The fight for power and ideology was even stronger for the Christiandemocrats, KDNP was abolished after an extremist leader Gyorgy Giczy won the internal battle and the majority of their MP's went to ${ }^{111}$.

\footnotetext{
${ }^{109}$ Allan Day, op.cit, pp. 308

${ }^{110}$ Janusz Bugajski, op.cit., pp. 358

${ }^{111}$ Allan Day, op.cit, pp. 310
}

Having in mind 15 years of multipartism and comparing them with the classical theory of the cleavages, Markus identified the following aspects:

The evolution of the Hungarian party system confirms the classical sequence of European cleavage formation with the initial and decisive emergence of identity-based territorial and cultural divides followed later by the appearance of economic cleavages. The salient expression and accumulation of cultural and territorial cleavages with their dominance over socio-economic divides in the party system corresponds clearly with the cyclical movement in the framework of the Rokkanian scheme manifesting now global the centrality of a nationalsupranational divide (Touraine). Hungarian party competition seems to reflect and even to anticipate new developments of Western party systems.

There are real historical alternatives expressing different conceptions of modernization, of nationhood and of geopolitical location represented by the parties. These alternatives are older than the electorate, but in their political representation they deviate from the mainstream in Western Europe: we find no direct link between the changing parties and the frozen alternatives. This is a consequence of discontinuity, of the totalitarian and authoritarian rules prior to 1989.Thus; we have to do with a particular form of 'freezing'. For Rokkan and Lipset, party alternatives and the party system itself freeze. In Hungary and in some other ECE countries, e.g. in Poland (Tworzecki) parties, partisan identities change in rather short intervals, parties 
and party structure is unstable and fluid. But the alternatives contained in the cleavage structure are amazingly stable: not the party system, but the cleavage structure is frozen. In the formation process of the parties (198889 ), in the subsequent three elections from 1990 to 1998 , the same cleavage sets have mattered and structured party competition, namely: the three cleavage families of Westernization vs. traditionalism, post-Communism vs. anti-post-Communism and promarket co modification (winners) vs. welfare statistic decommodification (losers). While in Western democracies parties are rooted in cleavages, to be more exact, are tied to distinct cleavage sides most Hungarian parties are either in search for social and cultural cleavages to embark upon, even crossing the cleavage lines, or are rooted in opposite cleavage sides . Thus, Sartori's thesis about the autonomy of actors in structuring the political space also has a strong explanatory power for Hungarian politics. This flux of party identities is, in recent years, to a certain extent, a tendency present in West European party systems, as globalization and the emergence of an information society transforms the cleavage basis of the established party systems. (Touraine) The evolutionary process of party politics in Hungary, in spite all contradictions, goes in the direction of more structure, more system, and combining, however, cross-cutting and mutually reinforcing cleavages.

This special freezing of alternatives and cleavages has, however, taken place in the context of a very much open and available electoral market. This deviance from the Rokkan-Lipset freezing pattern is the unavoidable consequence of the long discontinuity of the party system, the lack of traditions of mass democracy and the unstable interest structure of civil society. Although there are some sociological and demographic explanatory factors of party support, the overall tendency is volatility, an extremely low degree of party identification coupled with an inherited non-participatory political culture with apathy or even hostility towards parties. (Gazsó-Stumpf, Körösényi 1998) Parallel with the tendency of realignment, i.e. clear poles, and of alignment on the level of political actors, we also observe a massive realignment on the level of (non-)voters.

Due to the strong economic, social and political positions of the postcommunist elites and surviving value orientations in the electorate, 'the definition of the rules of the game" as a systemic issue (Offe 1991, Mair 1997) it is expressed by the salience of a 'post-Communism - anti-postCommunism' cleavage family. It cannot be deducted from the RokkanLipset scheme and by its very nature, cannot become a long-enduring historical divide, but can be supposed to fade away. That development might bring about a restructuring the cleavage basis and the party system itself in the non-distant future.

The taming of capitalism, the political regulation of the market with a political mobilization along a co modification - decommodification axis is a crucial point of democratic consolidation and legitimacy. Following from the freezing of the Hungarian political cleavage structure in the phase of the dominance of the 
cultural-territorial and post-communist cleavage families, the increasing importance of this socio-economic divide is coupled with its absorption by or inclusion into the other two cleavage families.

The post-1989 evolution of the Hungarian party system has brought about no political mobilization along the line of a classical labour-capital class cleavage. Instead, we have observed the following attempts for bringing the welfare statistic decommodification cleavage in:

- coupling it with the post-communist cleavage as the defense or restoration of certain pre-1989 structures and values and with the contradictory evolutionary transformation of the post-communist Socialist Party being a member of the transnational political family of social democracy;

- coupling it with the defense of national identity, a national path of modernization in face of a global supranational capitalism, in form of a stronger representation of nationhood and the nation state;

- coupling it with the religious cleavage, with Christian values, especially in a context, in which there is a correlation between poverty, marginalization and church-going frequency; - coupling its radical variant (anticapitalism) with an aggressive, xenophobic, authoritarian and fundamentalist social nationalism as the post-communist equivalent of e.g. the French frontism of Le Pen ${ }^{112}$. Ideological Party Families

The European parties families are created on the basis of four criteria. The first one is the party origins, the socio-historical conditions of party

112 Janusz Bugajski, op.cit, pp. 360-361 appearance and the interest they represent. The second is represented by the international contacts and ties the parties establis and maintain, the member quality in trans-national party federations or institutionalised multinational party groups. The policies a party proposes is another element and the last one is the political values that shapes the parties' programmes $^{113}$. This typology can be successfully applied in the case of Hungarian parties. The only difficulty we encountered was related with the values that shape the party programmes in Hungary, we based our typology only on the policies they applied. The selection criterion was at least a Parliamentary presence after 1989. We will follow the same features in the case of each party and we used the ideological families established by Gallagher, Laver and Mair.

The Hungarian Socialist Party (MSzP) belongs to the socialist and socialdemocratic party family and was created from the reformist wing of the ex-leader party, The Hungarian Labor Socialist Party, in October $1989^{114}$; it is a catch-all party and it represents the workers', pensioners', managers', administrators' and cultural elite interests. It is full member of the

\footnotetext{
${ }^{113}$ We can also consider the parties presented by S.Neumann :The Party of individual Representation and The Party of Social Integration from S.Neumann, The Party of Democratic Integration, in Peter Mair (ed.) The West European Party System. Oxford: Oxford University Press, 1990. (Oxford Readings in Government and Politics.) pp. 46-49

${ }^{114}$ Richard Katz \&Peter Mair, Changing

Models of Partz Organiyation and Party Democracy, 1995, Sage Publication, pp. 23
} 
Socialist International ${ }^{115}$. Between 1994-1998, MSzP followed an economic policy and imposed austerity budgets, the Bokros Plan being a famous reform they applied. The liberal wing dominated the traditional-elitist anti-market wing andit imposed its policies ${ }^{116}$. If the political institutions before 1989 can be considered legislative structures, the Parliamentary origin of $\mathrm{MSzP}$ is obvious.

The Free Democrats Alliance (SzDSz) belongs to the liberal family, it has its roots in the democratic movement from the 70's and 80's. Starting with the latest years of the 70's, the group was opposed to Communism, without any compromise and it stressed the Western democratic values, rights and liberties $^{117}$. It is a full member of the Liberal International $^{118}$. SzDSz strsses on the importance of a freee market in economic development and the full respct for the rule of law. It was a supporter of the privatisation and budgetary discipline. It represents the upper-middle class from urban area with a high education level. It developed strong ties with minorities' groups and it sustained the

115 Giovanni Sartori Parties and Party Systems. A Framework for Analysis. Vol. I. Cambridge: Cambridge University Press, 1976, pp. 61-63.

116 Janda, Kenneth „Comparative Political Parties: Research and Theory.", in Ada W. Finifter (ed.) Political Science. The State of the Discipline II. Washington D.C.: American Political Science Association, 1993. pp. 166

${ }^{117}$ Mair, Peter ,The Electoral Universe of Small

Parties in Postwar Western Europe.", in Ferdinand Müller-Rommel-Geoffrey Pridham (eds.): Small Parties in Western Europe. Comparative and National Perspectives. London: Sage Publications, 1991. pp. 44

118 Lane, Jan-Erik \& Ersson, Svante O. Western Politics and Society Europe, $3^{\text {rd }}$ edition, SAGE Publications, 1994, pp. 175 enlargement of their rights and involvement in the political and economic process ${ }^{119}$. The origin of this party is outside the Parliament as it was generated by the democratic movements from 70's and 80's.

The Young Democrats Alliance (Fidesz) belongs to the liberal family and it was created in 1988 by the students that reăresented the antiCommunism generation. It became a member of the Liberal International soon after that. As a centre-right party Fidesz took the middle-class votes. During its governing period, 19982002 , it was accused of an aggressive style that produced indignation among Hungary's neighbours ${ }^{120}$ (its position towards the Hungarian minorities from the neighboring countries). This party was also formed outside the Parliamentary arena, the initiative belonging to some groups of students.

The Hungarian Democratic Forum (MDF) belongs to the Christiandemocrats family, it was created in September 1988 having as main goal "to build a bridge between state and society". It is afiliated to the ChristianDemocrat International and to the Democratic Union International $^{121}$. It was composed of three main ideological orientations: Christiandemocrats, national-populists and national-liberals; all of them were

119 Lane, Jan-Erik \& Ersson, Svante O. Western Politics and Society Europe, $3^{\text {rd }}$ edition, SAGE Publications, 1994, pp 176

120 Lane, Jan-Erik \& Ersson, Svante O., Western Politics and Society Europe, $3^{\text {rd }}$ edition, SAGE Publications, 1994, pp. 176

${ }^{121}$ Maurice Duverger, The Two - Party System and the Multiparty System, in Peter Mair (ed.) The West European Party System. Oxford: Oxford University Press, 1990. (Oxford Readings in Government and Politics.) pp. 285295 
recognized as integrating parts of the Forum. The party represents the centre-right on the ideological axis and it was oriented towards a radical anti-Communist position ${ }^{122}$. Economically speaking, MDF chose a moderate reform in the economic sector. Its origin is outside the Parliament.

The Christian-Democrat Popular Party (KDNP) belongs to the Christiandemocrats family. In 1988, many members of the Democrat Popular Party created a civil association (Marton Aron Society) in order to gather the Hungarian Christiandemocrats. It was established as party starting with 1989. An antiCommunist profile was combined with welfare state positions. It is, ideologically speaking, on the right of the political centre ${ }^{123}$ and it is not afiliated to any international or transnational federation. Its roots are outside the Parliament.

The Independent Smallholders' Party (FKgP) belongs to the Agriarian family, it was created at the beginning of the 20's and it was well represented in Parliament before World War I. So, its origins are inside the Parliament. The party was revitalised in 1989 and it was the coalition partner of MDFin the first government after 1989. It wanted to atract the votes from rural area even though its traditional

122 Jean Blondel, Types of Party System, in Peter Mair (ed.) The West European Party System. Oxford: Oxford University Press, 1990. (Oxford Readings in Government and Politics.), pag.302-310, pp. 308

${ }^{123}$ R.A.Dahl , Party Systems and Patterns of Opposition, in Peter Mair (ed.) The West European Party System. Oxford: Oxford University Press, 1990. Oxford Readings in Government and Politics, pp. 298-301 electoral basis, the small farmers, suffered from colectivization durin $\mathrm{g}$ the Communist period ${ }^{124}$. Their main political plan was to give back the properties to their former owners, it is afiliated to the Christian-democrat International $^{125}$.

The Hungarian Life and Justice Party (MIEP) belongs to the right wing family. It was created by Istvan Csurka, a former member of MDF who was excluded from the party in June 1993. Its platform includes a reform of the privatisation and the abolishment of the anti-Hungarian discrimination, the establishment of a civil national guard and a civil repressive movement. According to its own web page, the party called itself "the voice of the national radicalism". In 1998, The European Council, in its report spoke about MIeP as a "antisemit and xenofobic party"126. Its roots are Parliamentary, being created by MP's from MDF. As it was created in 1993 , its continuity is big because the number of secessions and fusions is 0 so the level of institutionalisation is medium.

Organizational Aspects

In Western parties development it can be seen a series of levels starting with the $19^{\text {th }}$ century until now: the cadre party, the mass party, the catch-all

124 Markus, Gyorgy, Party Politics, Party System and the Dynamics of Political Cleavages in Hungary - Budapest, June 1998, pp. 299

125 Seymour Martin Lipset-Stein Rokkan „Cleavage Structures, Party Systems and Voter Alignments" in Peter Mair (ed.) The West European Party System. Oxford: Oxford University Press, 1990. (Oxford Readings in Government and Politics ), pp. 91-138

${ }^{126}$ Jan-Erik Lane \& Svante O. Ersson, Politics and Society in Western Europe, $3^{\text {rd }}$ edition, SAGE Publications 1994 , pp. 174 
party, the cartel party ${ }^{127}$ we will not going to offer details regarding the characteristics of these party types, we will try to identify the elements that correspond to those of type parties. The vast majority of Hungarian political organizations were constituted at the end of the 80 's as alternatives to the Communist Party. At the beginning, these had a small number of members; they evolved afterwards towards a superior level of sympathy and popularity. If we take a look at their initial programmes, we will find goals as democratization, decolectivization, European cultural integration and so on. After a while, the programmes were similar, they were approaching general interest subjects, and they were exactly like the catch-all parties.

After adopting the pluralist democracy form Western Europe, the parties started to become real aggregative forms, having as main characteristics the interest for the government policies, short-term results, political competition, and using resources from a variety of sources. This represents the fact that the Hungarian parties became real brokers between civil society and the state. The new evolutions and necessities of the Hungarian society on its way towards a consolidated democracy determine organizational changes at party levels. The level of relevant political resources distribution has the tendency to be a diffuse one; meanwhile the politics becomes more a "profession

127 Wolinetz, Lawson \& Merkl, Mair \& Smith, în Jan-Erik Lane \&Svante O. Ersson , Politics and Society in Western Europe, $3^{\text {rd }}$ edition, SAGE Publications 1994, pp 175 than a vocation" ${ }^{22}$. The competition type started to change and the cartel party is in pole position (competitive $=>$ contained ). This reality can be easily observed; the parties have regular access to national communication channels. Having in mind these features, we would like to point out that after the economic, social and political stability was obtained, after the transition to this type of stability was accomplished, the type of party that fits best to this reality is the cartel party. In Hungary, the transition towards the cartel party is in intermediary phase.

\section{The Post-Communist Hungarian Party} System

Beginning with the 1989 revolutions, the party system experienced a major change and this allows us to analyze Hungary's situation according with the Occidental methodology from stasiology. So, if before 1989, such an approach was meaningless, nowadays it is required exactly because of these major changes. Analyzing the Hungarian party system, the main theoretical framework we will use is the typology introduced by Giovanni Sartori $^{129}$. First, Sartori classifies the party systems according to one criterion used by the stasiologist researchers, and these criteria are the numerical ones. He introduces, beside the numerical aspect, also the concept of relevance aiming to distinguish the parties that has to be considered in the analysis. The two rules he formulated

${ }^{128}$ Our idea is that we can speak about stability in this part of Europe but a very different stability which is not generated by a competitive, free system.

${ }^{129}$ Giovanni Sartori Parties and Party Systems. A Framework for Analysis. Vol. I. Cambridge: Cambridge University Press, 1976, pp. 323 
are the distinction between relevant parties and the irrelevant ones. Applying this criterion, we reached the conclusion that there are five parties that have coalition potential, and these parties are MSzP, FideszMPP, MDF, FKgP and SzDSz. A second observation concerns the fact that there is no relevant anti-system party that has blackmail potential.

According to Sartori's classification, Hungary fits in the class of limited pluralism having five relevant parties. In order to cross from classification to typology, Sartori introduces a second dimension, the ideological one, indicating meanwhile the polarization degree of the party systems. Taking into account the fragmentation concept, he explains very simple that "few parties present low fragmentation while many parties [resent high fragmentation" ${ }^{\text {"130. }}$ Briefly, the more relevant parties are in a party system, the more the system is fragmented. The essential fragmentation condition is that "any of the parties does not reach the absolute majority"131.

Regarding the polarization concept, this indicates first the ideological distance which is, in fact, the second variable introduced because the numerical variable proved its limits. Thus, the ideological distance represents "the spread radius of the ideological spectrum of any political shape $^{, 132}$. By applying this variable,

${ }^{130}$ Giovanni Sartori Parties and Party Systems. A Framework for Analysis. Vol. I. Cambridge: Cambridge University Press, 1976, pp. 323

${ }^{131}$ Giovanni Sartori Parties and Party Systems. A Framework for Analysis. Vol. I. Cambridge: Cambridge University Press, 1976, pp. 323

${ }^{132}$ Giovanni Sartori Parties and Party Systems. A Framework for Analysis. Vol. I. Cambridge: Cambridge University Press, 1976, pp. 325-326 we pass from class to type. Briefly, if we have a low fragmentation, (top five parties), then, numerically speaking, we have limited pluralism, but if we add the ideological criterion, a small ideological distance, we have the moderate pluralism type. On the other hand, in the case of a high fragmentation (over five parties) to which corresponds the extreme pluralism, correlated with a high ideological distance, then we have the polarized pluralism type. Thus Sartori modifies the primary classification, based exclusively on numbers, using the second criterion, the ideological one. The result: a typology!

Relevance and Electoral Strength

Analyzing the party system in Hungary, the first aspect we will stress on will be the concept of "relevance" introduced by Giovanni Sartori ${ }^{133}$. Although he stresses first on the electoral power of the parties following the seats configuration from the inferior chamber of the Parliament in order to determine the size of parties and he tries to apply to them afterwards the "relevance" criterion, we will proceed a little bit different and we will try to apply to all the parties (not only the small ones) to this criterion). We will proceed like this because, as Sartori says, "a party relevance is a function not just a relative distribution of the power"134; existing even limit-cases when a party, despite the fact that it had a small electoral average was extremely

\footnotetext{
133 Sartori, Giovanni „A Typology of Party Systems.", in Peter Mair (ed.) The West European Party System. Oxford: Oxford University Press, 1990. (Oxford Readings in Government and Politics.), pp. 319

${ }^{134}$ ibidem, pp.319
} 
relevant ${ }^{135}$. We will consider a party as being relevant if, during its existence, participated at least in one coalition or, in Sartori's words, it has coalition potential. A second criterion refers to the big parties' blackmail potential (known as anti-system) which due to their ideological position, do not have coalition potential. What confers blackmail potential to this ideologically incommode party is exactly "its intimidation power (veto power)"136 reported at electoral power. Briefly, "we have to count all the parties which have either government relevance in forming the coalition, either competitive relevance in opposition“"137.

Another aspect that has to be clarified is that relevance represents an eliminating criterion so the parties that do not pass this "test" will not be taking into consideration for the analysis. Taking this into consideration we will take a look at the parties from the Hungarian Parliament in the period 1990-2003 having as premise that only the parties which obtained seats in the legislative can be relevant.

At a glance we would be tempted to admit as being relevant six parties: MSzP, Fidesz-MPP, MDF, FKgP, $\mathrm{SzDSz}$ and KDNP. Although, just five are relevant because KDNP evolution, despite its participation in a coalition, is cut in 1997 when the Parliamentary section of the party decided to cooperate with Fidesz and they divide forming $\mathrm{MKDSz}$ (The Hungarian Christian-Democrats Federation). As we have seen previously, Hungary has

\footnotetext{
${ }^{135}$ ibidem - Italian Republican Party, pp. 319

${ }^{136}$ idem, pp. 322

${ }^{137}$ idem, pp. 321
}

a number of five relevant parties and its system has to be integrated in the limited pluralism class. Regarding the second dimension, we can notice that the ideological distance between the Hungarian parties is relatively small and two can be the reasons of this: there is no relevant anti-system party and all five parties are oriented through the centre, thus "the leftist" party, MSZP, is more centre-left while MDF, which is "the rightest" is not far from the centre, having an ideology that is oriented towards centre rather than extreme. A scale could look like the one in figure number $3^{138}$.

Making a correlation between the two variables we reached the conclusion that Hungary presents the type of moderate pluralism. The most important feature of this type is the fact that, usually, the government is realized in coalition and this happens because almost all the time a party does not obtain the majority in the legislative. Hungary is not an exception, in the short postCommunist period there was no case in which a party to obtain over 50 per cent of the total amount of votes in order to form a monocolor government $^{139}$. Of course, one party obtained majorities in coalitions but never a party governed by its own. Another feature of the moderate pluralism is that it presents "a bipolar coalition configuration", more precisely it has the tendency to imitate the bipartism dynamics and it is very close to that one in Sartori's typology.

\footnotetext{
138 Initially we wanted to calculate the polarization indicator but we do not think it was relevant because the values are given by me, not by specialists.

139 There were majorities in the legislative regarding the number of seats
} 
And it imitates very well, the differences being very small: in two party systems we have two classical parties; in the moderate pluralism type we have "polar alignments of alternative coalitions" $"$. To point out the features of moderate pluralism, Sartori compares it all the time with polarized pluralism. Thus, by missing the relevant anti-system party and double oppositions, the moderate pluralism can be easily identified and Hungary is no exception to this rule. As a consequence, the Hungarian parties are oriented towards government, the parties would like to have both the possibility to participate in the governing process, the party competition being central in the sense that the parties try to reach positions as close to the centre of ideological axis or, as Sartori uses it, the competition is centripetal. .As can be seen; always the parties situated in opposition, compared to the ones that govern, situate themselves either to the right of the ideological spectrum, either to its left.

The electoral system. Gallagher disproportional indicator. The effective number of parties and the party system.

The Hungarian electoral law, as it is written in the specialty literature is one of the most complex in the world, two ballot mixed system. And this because it combines three different systems: uninominal vote, on districts, the list vote where the population votes parties in territorial districts (proportional representation) and a

140 Sartori, Giovanni „A Typology of Party Systems.", in Peter Mair (ed.) The West European Party System. Oxford: Oxford University Press, 1990. (Oxford Readings in Government and Politics.), pp. 336 compensatory allocation of some mandates from the compensation national lists. A first important consequence that can be observed is the fact that the disproportional indicator of the Hungarian electoral system will be higher than the one of the electoral systems based on PR and we will see why. Arend Lijphpart said that "RP systems and the two scrutiny ones encourage the multipartism". In fact, he wants to show that the electoral system has a great influence on the party system. Lijphart formulates another three important aspects of these tendencies: "all the electoral systems have the tendency to generate disproportional results, all the electoral systems have the tendency to reduce the effective number of parties reported to the real number of parliamentary parties and all the electoral systems can realize a fabricated majority"141.

In the case of Hungary, the first aspect can be calculated using the Gallagher indicator the results of the calculation in the case of Hungary can be seen in figure number 4. Comparing our results with the results obtained by Lijphart in his thirty-six democracies $^{142}$, with indicators that have variations between 1.3 (Netherlands) to 21.08 (France) and with an average of 8.11 , it can be seen that Hungary is very well situated on this chapter, being next to the average. What we are really interested in is a causality report between the disproportional indicator and the effective number of parties. This

\footnotetext{
${ }^{141}$ A.Lijphart, Modele ale democratiei ,Polirom 2000, Iasi, Romania, pp. 160

${ }^{142}$ Lane, Jan-Erik \& Ersson, Svante O., Western Politics and Society Europe, $3^{\text {rd }}$ edition, SAGE Publications, 1994, pp. 158
} 
relation is observed by Lijphart and it is very negative in the sense that by rising disproportional, the effective number of parties is decreasing. More precisely, "a raise by 5 per cent of disproportional is associated with a reduction of half of party in the case of effective number of parties"143. But this phenomenon takes place in the consolidated democracies about Lijphart is speaking and we cannot include Hungary in this category. Let's take a look of the effective number of parties in Hungary (Table $5)$.

Obviously, the causality relation cannot be applied in the case of Hungary and, in our opinion, it cannnot be applied in the case of Eastern Europe. There are few elements that can be reminded: the effective number of parties, which shows exclusively the power concentration in the legislative has, in this moment, almost half of its value in 1990. Is this a sign that Hungary has a tendency through bipartism? Sartori would say, and it seems to me more plausible, that this is only a feature of moderate pluralism - the party systems belonging to this type present a "bipolar coalition configuration that means that the system tries to imitate the bipartism mechanic with the specification that instead of classical opposite parties we have "bipolar alignments of alternative coalitions" $" 144$. Regarding the third aspect in Hungary there was a type of fabricated majorities in the sense that, for example, in 1994 elections, MSZP obtained 33 per cent

143 Lane, Jan-Erik \& Ersson, Svante O., Western Politics and Society Europe, $3^{\text {rd }}$ edition, SAGE Publications, 1994, pp. 163

${ }^{144}$ Giovanni Sartori, op.cit. pp. 336 of all votes and 209 mandates in the legislative which means 51.1 per cent $^{145}$. And we said a type because the disproportional does not explains by its own this difference, but the indicator has to be correlated with the electoral system. No doubt, it had more mandates because, on the one hand, the system have the tendency to over-appreciate "the big parties" as we stressed before, the disproportional being always in their favor, on the other hand, they obtained a series of mandates in the uninominal vote. There are, of course, also other causality relations between the electoral system and the party system like the circumscription magnitude but the lack of information does not allow us to analyze them too. A cause for the stability of the Hungarian party system, because we consider it to be stable, can be the fact that the electoral law was unchanged since 1989, a unique case in Central and Eastern Europe.

We will try to analyze the institutionalization of party system in Hungary using the criteria elaborated by Scott Mainwaring. From the four criteria we are going to eliminate the one that refers to the legitimacy of parties and elections among the population because it was impossible, due to the linguistic bias and the short time, to collect the information required for a proper analysis of the criteria / polls, population participation in the voting process, etc. the other three criteria we are considering are: stability in the pattern of competition between parties, party roots in society, party

\footnotetext{
${ }^{145}$ George Voicu, Pluralismul, o teorie a democratiei, Editura All, 1998, Bucureşti, pp. 249
} 
$\operatorname{organisation}^{146}$. Beside these we considered also the citeria that refers to the number of parties analysed using the effective number of parties and the cuantification that takes into account the party dimensions that looks in the following way:

a) Two and a half party system;

b) The system with a big party and few small parties;

c) The system with two big parties and few lot smaller parties;

d) Multiparty system ${ }^{147}$.

The stability in the competition patterns between parties

This criterion is operationalised using the electoral volatility that registered the following values among the electoral cycles: 1990-1994 -26,8; 1994-1998: 31,6; 1998-2002: 19, $1^{148}$. It can be observed a stability comparing with the average value of Eastern and Central Europe 35,3, calculated by Scott Mainwaring $^{149}$.

Party roots in society

The reduced volatility indicates us the fact that the parties managed to develop powerful roots in the sociey. Another indicator of the of the way in which the parties developed roots in society is their ability of surviving along a long period of time. All the four parties that exist in the current legislative have been present also in the frst legislative after 1989. It has to be mentioned the fact that $\mathrm{FKgP}$, from the moment of its coming into being during the 20's, was in the Hungarian

\footnotetext{
146 Scott Mainwaring - Party Systems in the Third Wave, pp. 3-4

147 Alan Ware, Political Parties and Party System, Oxford University Press, New York, 1996

${ }^{148}$ www.socsci.auc.dk/institut2/nopsa/ arbejdsgruppe6/sitter.pdf

149 Scott Mainwaring, Party Systems in the Third Wave, pp. 5
}

Parliament until the Communist regime came to power. Taking into account the data presented above we can conclude that the rootes of the Hungarian parties are deep, especially if we are comparing them with the party roots from other Central adnd Eastern European countries.

Party organization

The Hungarian parties developed very quickly their organization in a very short period. They managed not only to constitute themselves as parties, but also to stabylize themselves and to create structures that allowed them to develop their activity with high efficiency. The parties were, at the beginning, only general groups generated by the transformations from the Communist regime and its fall, the exception was called FKgP. There were made by individuals that grouped arround a leader or an idea. The parties improved gradually their organisational structure managing to transform themselves in parties that resembles to the Western European parties. The best example is $\mathrm{MSzP}$ which managed to transform itself into a modern aggregative party (catch-all party in Kircheimer's terms).

The number of parties

1. The effective number of parties the values of this indicator were the following in the after 1989 period: $1990-3,8 ; 1994-2,9$; $1998-3,4 ; 2002-2,2$.

2. The cuantification of the parties considering their dimensions. The party system resulted after the legislative elections in 1990 can be situated in the typology of two big parties and few lot smaller parties. The biggest party, MDF, obtained 42,4 per cent of parliamentary mandates, it was forced to make a government coalition 
with FKgP and KDNP. In 1994, the legislative elections generated a party system with a big party, MSzP, which obtained 54,1 per cent of the parliamentary mandates and more small parties. Although it was not forced, MSzP formed a government coalition with $\mathrm{SzDSz}$ for political strategy reasons. In 1998, the system came back to the one of two big parties and lot of smaller parties, the two big parties being Fidesz which got 38,3 per cent of parliamentary mandates and MSzP which got 34,7 per cent. Thus, Fidesz formed a government coalition with MDF and FKgP. In 2002, the system became two and a half party system. The only exception is that one party is actually an electoral coalition formed by Fidesz and MDF, which obtained 48,7 per cent of the parliamentary mandates, thesecond party was $\mathrm{MSzP}$ with $46,1 \%$ and $\mathrm{SzDSz}$ which got $5,1 \%$ was the"half".

The first three criteria indicate a high degree of party system institutionalization for Central and Eastern Europe, while the effective number of parties, which encounters a moderate variation, indicates an average range of institutionalization. The big number of changes of the party system regarding the cuantification whch takes into account the size of the parties indicates a low range of institutionalization.because each electoral process represented the beginning of a new system, only in 1998 we encountered, for the second time, the same system, the one of two big parties and several small parties.

Conclusions were written after every section analysed so the main part of the final conclusion was also mentioned and this is the reason why we will not repet it. Our main conclusion, after analysing the Hungarian political and electoral system, is that the progress made by Hungary is unique in this area and it has its specificity but there are several steps to make until full completing the road that Hungary started, but the premises are encouraging and following the same rhythm it will be more easy for Hungary to adapt its political aspects to the European requirements. 


\section{Occidentalists}

Competition axis

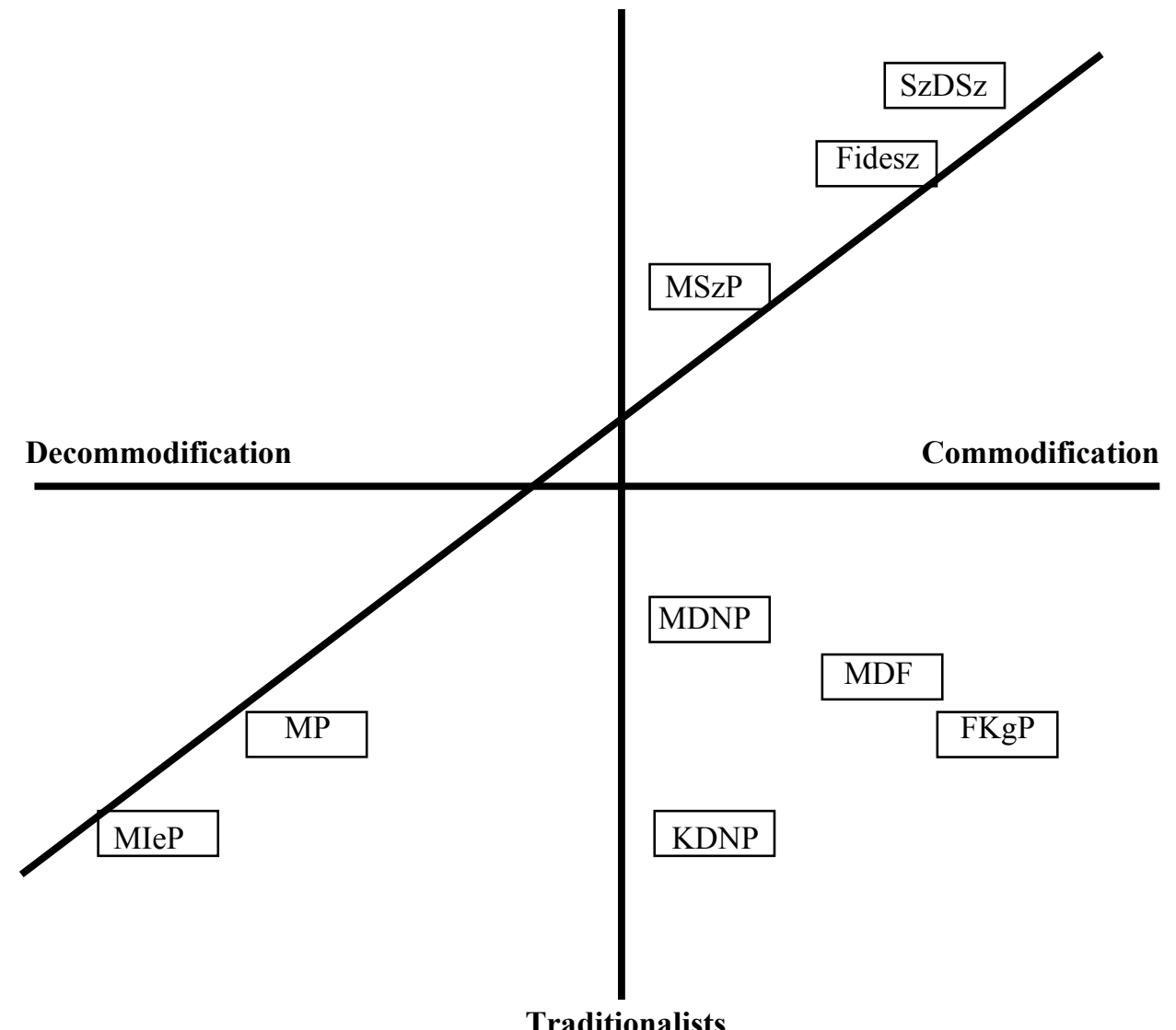

Traditionalists 
TABLES AND APPENDIX

Table 1. Electoral results in Hungary, 1945-2001.

\begin{tabular}{|c|c|c|c|c|c|c|c|c|c|c|c|c|}
\hline & \multicolumn{2}{|c|}{2002} & \multicolumn{2}{|c|}{1998} & \multicolumn{2}{|c|}{1994} & \multicolumn{2}{|c|}{1990} & \multicolumn{2}{|c|}{1947} & \multicolumn{2}{|c|}{1945} \\
\hline Party & $\%$ & Seats & $\%$ & Seats & $\%$ & Seats & $\%$ & Seats & $\%$ & Seats & $\%$ & Seats \\
\hline $\mathrm{MSzP}$ & 42,0 & 178 & 32,9 & 134 & 33,0 & 209 & 10,9 & 33 & 14,9 & 67 & 17,4 & 69 \\
\hline MPP & 11 & 165 & 29,4 & 148 & 7,0 & 20 & 8,6 & 21 & - & - & - & - \\
\hline MDF &, 1 & 23 & 2,8 & 17 & 11,7 & 37 & 24,7 & 164 & - & - & - & - \\
\hline FKgP & 0,8 & - & 13,2 & 48 & 8,8 & 26 & 11,7 & 44 & 15,4 & 68 & 57,0 & 245 \\
\hline SzDSz & 5,6 & 20 & 6,9 & 24 & 19,7 & 70 & 21,4 & 92 & - & - & - & - \\
\hline MieP & 4,4 & - & $\overline{5,5}$ & 14 & 1,6 & - & - & - & - & - & - & - \\
\hline$\overline{\mathrm{CP}}$ & 3,9 & - & 2,3 & - & 7,0 & 22 & 6,5 & 21 & 16,4 & 60 & - & - \\
\hline MP & 2,2 & - & 4,0 & - & 3,2 & - & 3,7 & - & 22,3 & 100 & 16,9 & 70 \\
\hline Others & 0,1 & - & 2,3 & 1 & 8,0 & 2 & 12,5 & 11 & 31,0 & 103 & 8,7 & 23 \\
\hline Total & - & 386 & - & 386 & - & 386 & - & 386 & - & 411 & - & 409 \\
\hline
\end{tabular}

MSZP: Hungarian Socialist Party; MPP: Hungarian Civic Party; MDF: Hungarian Democratic Forum;

FKGP: Independent Party of Smallholders; SZDSZ: Alliance of Free Democrats; MIEP: Hungarian Justice and Life Party; CP: Centre Party; MP: Workers' Party ${ }^{66}$

Table 2. Government Coalitions ${ }^{67}$

\begin{tabular}{|c|c|c|c|c|}
\hline & 1990-1994 & 1994-1998 & $1998-2002$ & $2002-$ \\
\hline Government Coalitions & $\begin{array}{l}\mathrm{MDF}+ \\
\mathrm{FKgP+} \\
\text { KDNP }\end{array}$ & $\begin{array}{c}\text { MSzP+ } \\
\text { SzDSz }\end{array}$ & $\begin{array}{c}\text { FIDESZ-MPP+ } \\
\text { MDF+ } \\
\text { FKgP }\end{array}$ & $\begin{array}{c}\text { MSzP+ } \\
\text { SzDSz }\end{array}$ \\
\hline
\end{tabular}

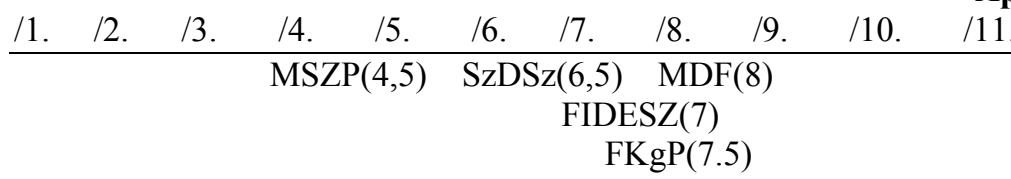

Table 4 - Table realized after own calculations

\begin{tabular}{|l|c|c|c|c|c|}
\hline Elections & 1990 & 1994 & 1998 & 2001 & Average \\
\hline Results: absolute number & 0.0611 & 0.0669 & 0.1729 & 0.1296 & 0.1076 \\
\hline Results:: per cent \% & 6.11 & 6.69 & 17.29 & 12.96 & 10.76 \\
\hline
\end{tabular}

Table 5

\begin{tabular}{|c|c|c|c|c|}
\hline Elections & 1990 & 1994 & 1998 & 2002 \\
\hline Number of Parliamentary parties & 7 & 6 & 6 & 3 \\
\hline Effective number of parties / coalitions & 3.8 & 2.9 & 3.4 & 2.2 \\
\hline $\begin{array}{l}\text { Source: compilation based on the index of effective parties realized by Laakso } \\
\text { and Taagepera }\end{array}$
\end{tabular}

\footnotetext{
${ }^{66} \mathrm{http}: / /$ www.parties-and-elections.de/hungary2.html

${ }^{67}$ Alan Day, Richard German , John Campbell, Political Parties of the World , $4^{\text {th }}$ edition, Catermill

Publications1996, pp.307-311;

www.phw.binghamton.edu/samplepages/html/hungary/political parties.htm

${ }^{68}$ www.socsci.auc.dk/institut2/nopsa/ arbejdsgruppe6/sitter.pdf
} 
References:

BLONDEL, Jean, Types of Party System in Peter Mair (ed.), 1990, The West European Party System. Oxford: Oxford University Press, (Oxford Readings in Government and Politics.), p. 302-310

BERGLUND Sten, DELLEBRANT Jan-Ake, 1991, The New Democracies in Eastern Europe, Trinitiy College, Dublin;

BUGASKI, Janusz, 2002, Political Parties of Eastern Europe. A Guide to Politics in the Post-Communist Era. Armonk, NY-London: The Center for Strategic and International Studies-M. E. Sharpe;

DAHL, R.A., Party Systems and Patterns of Opposition in Peter Mair (ed.), 1990, The West European Party System. Oxford: Oxford University Press, (Oxford Readings in Government and Politics ), p. 298-301

DAY, Alan, GERMAN, Richard, CAMPBELL, John, 1996, Political Parties of the World, 4th edition, Catermill Publications, p. 307-311

DUVERGER, Maurice , The Two - Party System and the Multiparty System, in Peter Mair (ed.), 1990, The West European Party System. Oxford: Oxford University Press (Oxford Readings in Government and Politics.), p. 285295

JANDA, Kenneth Comparative Political Parties: Research and Theory, in Ada W. Finifter (ed.) 1993, Political Science. The State of the Discipline II. Washington D.C.: American Political Science Association,

KATZ, Richard \& MAIR, Peter, 1995, Changing Models of Party Organization and Party Democracy, Sage Publication, p. 5-27;

LANE, Jan-Erik \& ERSSON, Svante O, 1994, Western Politics and Society Europe, 3rd edition, SAGE Publications;

LIJPHART, Arend, 2000, Modele ale democratiei, Polirom, IAŞI;

LIPSET, Seymour Martin, ROKKAN, Stein Cleavage Structures, Party Systems and Voter Alignments in Peter Mair (ed.) 1990, The West European Party System. Oxford: Oxford University Press (Oxford Readings in Government and Politics ), p.91-138

MACKIE, Thomas, ROSE Richard, 1991, The International Almanac of Electoral History. 3rd edition. Houndsmill: Macmillan;

MÁRKUS, Gyorgy, Party Politics, Party System and the Dynamics of Political Cleavages in Hungary, June 1998, Budapest,

NEUMANN, Sigmund, The Party of Democratic Integration, in Peter Mair (ed.) 1990, The West European Party System. Oxford: Oxford University Press,. (Oxford Readings in Government and Politics) pp. 46-49 
SARTORI, Giovanni A Typology of Party Systems, in Peter Mair (ed.) 1990 The West European Party System. Oxford: Oxford University Press,. (Oxford Readings in Government and Politics) pp. 316-349

VOICU, George, 1998, Pluralismul , o teorie a democratiei , Bucuresti ,All; http://www.parties-and elections.de/hungary2.html

www.phw.binghamton.edu/samplepages/html/hungary/political_parties.htm www.socsci.auc.dk/institut2/nopsa/ arbejdsgruppe6/sitter.pdf 